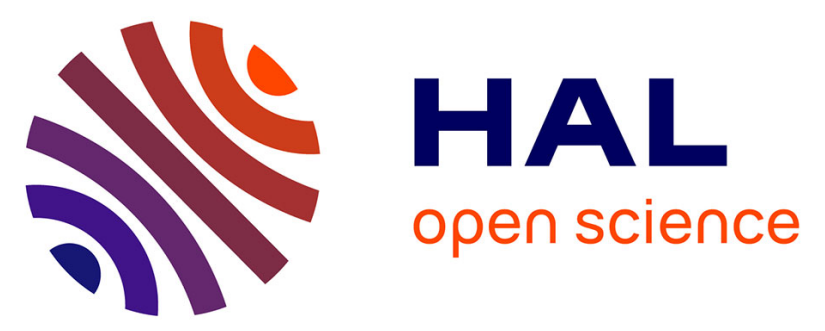

\title{
Silicon-based electrochemical microdevices for silicate detection in seawater
}

D Aguilar, C Barus, W Giraud, E Calas, Emilie Vanhove, Adrian Laborde, Jérôme Launay, Pierre Temple-Boyer, N Striebig, M Armengaud, et al.

\section{To cite this version:}

D Aguilar, C Barus, W Giraud, E Calas, Emilie Vanhove, et al.. Silicon-based electrochemical microdevices for silicate detection in seawater. Sensors and Actuators B: Chemical, 2015, 211, pp. 116-124. 10.1016/j.snb.2015.01.066 . hal-01225642

\section{HAL Id: hal-01225642 \\ https://hal.science/hal-01225642}

Submitted on 20 Nov 2015

HAL is a multi-disciplinary open access archive for the deposit and dissemination of scientific research documents, whether they are published or not. The documents may come from teaching and research institutions in France or abroad, or from public or private research centers.
L'archive ouverte pluridisciplinaire HAL, est destinée au dépôt et à la diffusion de documents scientifiques de niveau recherche, publiés ou non, émanant des établissements d'enseignement et de recherche français ou étrangers, des laboratoires publics ou privés. 


\section{Silicon-based electrochemical microdevices for silicate detection in seawater}

D. Aguilar ${ }^{a^{*}}$, C. Barus ${ }^{a^{*}}$, W. Giraud ${ }^{a}$, E. Calas ${ }^{a}$, E. Vanhove ${ }^{b, c}$, A. Laborde ${ }^{b, c}$, J. Launay $^{b, c}$, P. Temple-Boyer ${ }^{b, c}$, N. Striebig ${ }^{d}$, M. Armengaud ${ }^{d}$, V. Garçon ${ }^{a^{*}}$

"2 first co-authors

'Laboratoire d'Etudes en Géophysique et Océanographie Spatiales, UMR 5566, 18 Avenue Edouard Belin 31401 TOULOUSE Cedex 9, France ${ }^{\mathrm{b}}$ CNRS, LAAS, 7 Avenue du Colonel Roche, F-31400 TOULOUSE, France 'University of Toulouse, UPS, LAAS, F-31400 TOULOUSE, France

dObservatoire Midi-Pyrénées, 14 Avenue Edouard Belin 31401 TOULOUSE Cedex 9 , France

${ }^{*}$ Corresponding author. E-mail: carole.barus@legos.obs-mip.fr; Tel.: +33 5613329 13; fax: +33 561253205 


\section{Abstract}

This paper describes the electrochemical characterisation of gold and platinum microdevices mass fabricated using silicon technology. Specific attention was paid to allow in situ electrochemical detection of silicate in seawater. Thus, using a silicon nitride $\left(\mathrm{Si}_{3} \mathrm{~N}_{4}\right)$ inorganic passivation layer patterned using Inductively Coupled Plasma Chemical Vapor Deposition (ICP-CVD), coupled with a non-aggressive lift-off based process, different electrodes were isolated electrically: one gold or platinum working electrode named "macroelectrode" (2 mm of diameter), four gold or platinum working ultramicroelectrodes (UME) (15 $\mu \mathrm{m}$ of diameter), one platinum counter electrode and one silver electrode which can be used as a reference electrode after its chlorination. Their small size and mass fabrication make them very promising for oceanographic applications. As some components of microdevices release silicate and contaminate the solution, after being immersed in seawater, these microdevices were inserted in a specific cell that only puts the electrodes in contact with the seawater solution. Gold has been tested as a possible material for working electrodes but its lack of adherence to the passivation layer in seawater solutions led to non-accurate measurements. On the contrary, passivation layer on platinum electrodes resists to the seawater corrosive medium. The analytical performances of the platinum microdevices has been tested through different silicate calibrations and shows an outstanding accuracy and reproducibility when measurements are performed, especially with the macroelectrodes which showed only $2.8 \%$ signal variation after four months of use and a limit of quantification of $0.50 \mu \mathrm{mol}^{-L^{-1}}$ suitable for oceanographic applications.

Keywords: Silicon microdevices; electrochemistry; in situ silicate detection in seawater

\section{Introduction}


Continuous monitoring and real time transmission of key parameters from marine environments, such as macro-nutrients (silicate, phosphate, nitrate) help to better understand biogeochemical cycles and the role of the ocean in climate evolution. As of September 2014, 3579 ARGO floats equipped with physical CTD (conductivity, temperature, depth) sensors were profiling in the global ocean. Some of these floats were equipped with biogeochemical sensors (Oxygen (249), Bio-optics (77), Nitrate (47) and $\mathrm{pH}(14))$ but none of them with a silicate one. An important challenge is to cover the ocean with as many biogeochemical profiling floats as physical floats. To reach this goal, in situ and autonomous nutrient sensors are needed to sample the largest range of spatio-temporal scales. In order to implement nutrients sensors on buoys, moorings, autonomous under vehicles, floats..., these sensors have to be robust and resistive to corrosive conditions, miniaturized, portable, may consume low energy, and be low cost. Electrochemistry has been chosen here to detect silicate because electrochemical methods may fulfill some of these requirements.

As a matter of fact electrochemistry is routinely used in analytical chemistry and provides a large scope of applications, in increasingly complex samples [1-4]. In marine environments, Reimers [5], Moore et al. [6] and Denuault [7] reviewed the electrochemical techniques and microelectrodes used into sensors for oceanic research. Mainly, there are four electrochemical methods used in oceanography using in situ commercial sensors: (i) impedimetry to measure conductivity and determine salinity [8], (ii) potentiometry to measure $\mathrm{pH}$ [9-13] and $\mathrm{pCO}_{2}[14,15]$, (iii) amperometry to measure dissolved oxygen using Clark sensors $[16,17]$ or STOX sensors $[18,19]$ and (iv) voltammetry for trace metals and speciation monitoring [20, 21]. In the last recent years, combination of modern electrochemistry with progress in microelectronics and microfabrication has allowed to develop new microarrays, flowcells and microsensors for real-time monitoring of trace metals $\left(\mathrm{Pb}^{2+}, \mathrm{Cd}^{2+}, \mathrm{Cu}^{2+}\right.$, $\left.\mathrm{Mn}^{2+}, \mathrm{Co}^{2+} \ldots\right)$ in seawater using screen-printed electrodes $[22,23]$ or silicon-based 
microelectrodes [24-27]. Cathodic [28] and anodic [29] stripping voltammetry methods are widely used for metals speciation, more often combined with square wave voltammetry (Square Wave Anodic Stripping Voltammetry SWASV) [30-32]. These methods are using either gel integrated Ir-based microelectrodes [21, 33, 34] or gold amalgam electrodes [20,35-37] and allow to detect simultaneously several redox species in seawater within a single potential scan $\left(\mathrm{O}_{2}, \mathrm{Mn}^{2+}, \mathrm{Fe}^{2+}, \mathrm{I}^{-}, \mathrm{FeS}, \mathrm{S}^{2-}\right.$, $\left.\mathrm{H}_{2} \mathrm{~S} \ldots\right)$.

It is now possible to detect silicate with electrochemical methods without any addition of liquid reagents even if silicate is a non-electroactive species and so cannot be detected directly. Indeed, Lacombe et al. developed a method to produce in situ the reagents and the $\mathrm{pH}$ conditions needed to form the Keggin anion $\mathrm{Si}\left(\mathrm{Mo}_{12} \mathrm{O}_{40}\right)^{4-}$ detectable by cyclic voltammetry on gold or platinum electrodes [38]. This method requires a simple oxidation of a molybdenum electrode in order to form molybdate and protons. To achieve the needed acidic $\mathrm{pH}$ and form the silicomolybdic complex, a non-proton exchange membrane is added in order to isolate the counter electrode and avoid the reduction of the $\mathrm{H}^{+}$formed at the anode [39]. We are currently working on the development of miniaturized and autonomous silicate sensors using this method and in order to reduce the associated cost, the use of silicon-based technologies for the mass fabrication of electrodes and the realization of integrated microdevices is proposed.

Development of microfabricated electrochemical devices (microelectrodes, microelectrode arrays and ultramicroelectrodes) has considerably increased in the last two decades [40]. The advantage of this technique is to create individual microdevices with identical physical and chemical performances, well defined and reproducible geometries of several electrodes with a mass fabrication approach. Several metals such as gold, platinum, silver..., can be deposited on silicon-based microdevices. The final capping insulation layer (passivation layer), which isolates the 
circuit and defines the electrode surface area, is the critical step in the microfabrication process. Passivation layers can be either organic or inorganic.

Organic passivation layers such as polymers are generally deposited by spin coating processing and were used for medical applications [41, 42]. However, organic passivation layers suffer from water adsorption and are not suitable for liquid media such as seawater. The time of failure in such environment is in the range of a few hours [43].

Inorganic passivation layers such as silicon oxide $\left(\mathrm{SiO}_{2}\right)$ or silicon nitride $\left(\mathrm{Si}_{3} \mathrm{~N}_{4}\right)$, deposited by Plasma-Enhanced Chemical Vapor Deposition (PECVD), give excellent electrical barrier properties and resist much longer in fluids than polymers. Microdevices with these inorganic passivation layers were used to evaluate the quantity of herbicides in natural waters measuring the variations in consumptionproduction rates of species involved in metabolic activities of algae such as $\mathrm{O}_{2}, \mathrm{H}_{2} \mathrm{O}_{2}$, and $\mathrm{H}_{3} \mathrm{O}^{+} / \mathrm{OH}^{-}$ions [44]. Tercier-Waeber et al. developed a multi physical-chemical profiler for in situ monitoring of $\mathrm{Cu}(\mathrm{II}), \mathrm{Pb}(\mathrm{II})$ and $\mathrm{Cd}(\mathrm{II})$ in estuaries and coastal seawaters [21].

However, environments such as seawater where the chloride concentration is really high cause important damages on passivation layers. Indeed Nolan and Kounaves revealed that both chloride $\left(\mathrm{Cl}^{-}\right)$concentration and acidity of the solution contribute to microdevice failure because of $\mathrm{Cl}^{-}$infiltrations underneath the insulating layer [45].

Schmitt et al. compared different passivation layers in $\mathrm{NaCl}\left(1 \mathrm{~mol} . \mathrm{L}^{-1}\right)$ solution at three different $\mathrm{pH}$ (i.e. $\mathrm{pH}=2,7$ and 10) and concluded that the best results in term of life time resistance were obtained with $\mathrm{SiO}_{2} / \mathrm{Si}_{3} \mathrm{~N}_{4}$ duplex layers and $\mathrm{SiO}_{2} / \mathrm{Si}_{3} \mathrm{~N}_{4} / \mathrm{SiO}_{2}$ triplex layers [43].

Vanhove et al. used this type of inorganic passivation layers and developed a new deposition process at low temperature which reduced surface damages and controlled residual stress using Inductively Coupled Plasma Chemical Vapor Deposition (ICP-CVD) coupled with a non-aggressive lift-off based process with T 
shaped photoresist profiles [46]. They immersed three microdevices with twelve gold ultra-microelectrodes (UME) during approximatively two months in seawater and did electrochemical cleaning in sulfuric acid $\left(\mathrm{H}_{2} \mathrm{SO}_{4}: 0.5 \mathrm{~mol} . \mathrm{L}^{-1}\right)$ by cyclic voltammetry, then chronoamperometry measurements at $0.6 \mathrm{~V}$ in $5 \mathrm{mmol}^{-1}$ solutions of potassium hexacyanoferrate (II) trihydrate in order to measure the electroactive surface areas of UME. They showed stable and reproducible results during 50 days.

In this work, we will present the results obtained with these new silicon-based microdevices developed by LAAS laboratory with $\mathrm{Si}_{3} \mathrm{~N}_{4}$ passivation layer for the electrochemical detection of silicates in seawater in the concentration range observed in the open ocean. We will describe the structure of the new microdevices that integrate a macroelectrode (ME), four ultramicroelectrodes (UME) and a counter electrode. The materials used for the electrodes will be discussed as well as how these devices have been adapted for the first time for the silicate detection in seawater.

\section{Material and methods}

\subsection{Microdevices fabrication}

The electrochemical microdevices were fabricated according to the ElecCell (Electrochemical microcell) silicon-based technological platform previously developed in LAAS [42]. Starting from an oxidized silicon wafer (oxide thickness: $\sim 1 \mu \mathrm{m}$ ) in order to ensure electrical insulation between the different metallic layers, the different thin metallic layers were deposited by evaporation in conventional Physical Vapour Deposition (PVD) equipment, and patterned using a bilayer lift-off process in order to improve fabrication reproducibility. Different PVD processes were performed in a row: firstly, a $200 \mathrm{~nm}$ platinum layer was deposited on a $20 \mathrm{~nm}$ titanium underlayer in order to ensure platinum adhesion on silicon oxide. Then other metallic layers could be deposited such as $400 \mathrm{~nm}$ gold (for working electrodes) and $400 \mathrm{~nm}$ silver that 
can be used as a reference electrode after its chlorination. Finally, an inorganic $\mathrm{Si}_{3} \mathrm{~N}_{4}$ passivation layer (thickness: $105 \pm 5 \mathrm{~nm}$ ) was deposited patterned using photolithography techniques [46]. This wafer-level passivation process was developed and optimized in order to fit with the long-term seawater analysis [46]. Through this final step, the different metallic layers were insulated electrically and their active surfaces were precisely defined. Finally, the different silicon chips were placed and glued by an epoxy insulating glue on a specifically coated printed circuit, wire bonded and packaged at the system level in order to be fully compatible with liquid phase analysis.

The dimensions of such a microdevice are $80 \mathrm{~mm} \times 15 \mathrm{~mm} \times 2 \mathrm{~mm}$ (Figure 1-A) and the photo shows one platinum counter electrode $(3 \mathrm{~mm} \times 1 \mathrm{~mm})$, one silver electrode ( $3 \mathrm{~mm} \times 1 \mathrm{~mm}$ ) to be used further as reference electrode, one working macroelectrode ( $2 \mathrm{~mm}$ of diameter) and four working ultramicroelectrodes (15 $\mu \mathrm{m}$ of diameter) (Figure 1-B and $\mathrm{C}$ ). The macroelectrode and ultramicroelectrodes are made of gold or platinum according to the fabrication process.

\subsection{Apparatus and electrodes}

Cyclic voltammetry measurements were carried out at room temperature with a potentiostat PGSTAT 128N (Metrohm) controlled by NOVA software. A multiplexer module (MUX) (Metrohm) allowed to connect several electrodes in the same time and to perform electrochemical measurements with the different macro- and ultramicroelectrodes from a microdevice, sequentially. All potentials are given versus an $\mathrm{Ag} / \mathrm{AgCl} / \mathrm{KCl}\left(3 \mathrm{~mol}^{-\mathrm{L}^{-1}}\right)$ (Metrohm) reference electrode.

The molybdenum slab was supplied by GoodFellow (purity, 99.9\%). To realize some contamination tests of the different components and material used into microdevices, homemade gold ultramicroelectrodes ( $25 \mu \mathrm{m}$ of diameter) were needed. They were prepared in the laboratory from gold wires purchased from GoodFellow and sealed 
with epoxy resin made with a mix of $\operatorname{DGEBA}^{1}(10 \mathrm{~g})+\operatorname{IPDA}^{2}(2.44 \mathrm{~g})$ and polymerized at $80^{\circ} \mathrm{C}$ during 3 days [47].

\subsection{Reagents and solutions}

All solutions were prepared in Milli-Q water (Millipore Milli-Q water system) and put into polypropylene containers because glass must not be used in order to avoid silicate contamination in solutions. Silicate solutions were prepared with sodium hexafluorosilicate $\left(\mathrm{Na}_{2} \mathrm{SiF}_{6}\right.$, from Merck) between 0.50 and $134 \mu \mathrm{mol} . \mathrm{L}^{-1}$. Standard calibration and silicate samples were prepared in sodium chloride $(\mathrm{NaCl})$ solutions supplied by Merck at $34.5 \mathrm{~g} \cdot \mathrm{L}^{-1}\left(0.6 \mathrm{~mol} \cdot \mathrm{L}^{-1}\right)$.

The electroactive surfaces of gold (especially for homemade electrodes) are activated using a 0.50 mol.L $\mathrm{L}^{-1}$ sulphuric acid solution (prepared from a $98 \% \mathrm{H}_{2} \mathrm{SO}_{4}$ solution supplied by Merck).

\subsection{General analytical procedure}

The methodology for the electrochemical determination of silicates with the microdevices is adapted from the one described in Lacombe et al. and consists of two steps [39]:

i) The molybdenum metal electrode oxidation is performed in a $3 \mathrm{~mL}$ sample by applying a constant potential of $1.0 \mathrm{~V}$ until a $14 \mathrm{C}$ electric charge was reached in order to form molybdates $\left(\mathrm{MoO}_{4}{ }^{2-}\right.$ up to a concentration of $\left.6.5 \mathrm{mmol} . \mathrm{L}^{-1}\right)$ and protons $\left(\mathrm{H}^{+}, \mathrm{pH} \approx 1.5\right)$. The cut off of the electric charge $(14 \mathrm{C})$ was determined experimentally as it is not possible to calculate it with the Faraday's law since the oxidation of molybdenum involves the formation of different Mo oxides as $\mathrm{MoO}_{2}$, $\mathrm{MoO}_{3} \ldots$ [48]. After 6 minutes with stirring, the corresponding $\beta$-silicomolybdic complex $\left(\beta-\mathrm{Si}\left(\mathrm{Mo}_{12} \mathrm{O}_{40}\right)^{4-}\right)$ is formed. This step is carried out in a homemade cell (see Figure 2) which is divided into 2 compartments separated by a Nafion ${ }^{\circledR}$ membrane

\footnotetext{
${ }_{1}^{1}$ DGEBA : DiGlycidyl Ether of Bisphenol A

2 IPDA : Isophorone Diamine
} 
(N117 DuPont ${ }^{\mathrm{TM}} \mathrm{PFSA}$ ). In the first compartment, $3 \mathrm{~mL}$ of sample is placed together with a molybdenum electrode and the reference electrode $\left(\mathrm{Ag} / \mathrm{AgCl} / \mathrm{KCl} 3 \mathrm{~mol} \cdot \mathrm{L}^{-1}\right)$. $\mathrm{A}$ platinum counter electrode is placed in the second compartment, on the other side of the non-proton exchange membrane, to limit the diffusion of $\mathrm{H}^{+}$produced, avoid their reduction and obtain the required acidic $\mathrm{pH}$ for the complexation of silicates with molybdates $[49,50]$.

ii) The silicomolybdic complex is then detected by cyclic voltammetry (CV) using a gold or platinum working electrode immersed in the compartment of the cell (Figure 2) which contains the Mo electrode. The cyclic voltammograms are performed

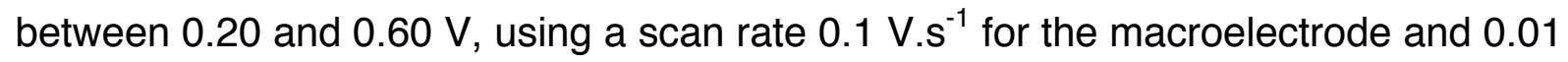
V. $\mathrm{s}^{-1}$ for the ultramicroelectrodes. The CV plots show two reduction peaks at $0.26 \mathrm{~V}$ and $0.38 \mathrm{~V}$ and two oxidation peaks at $0.31 \mathrm{~V}$ and $0.41 \mathrm{~V}$. In this work, the analytical signals have been either the intensity current in the reduction peak at $0.38 \mathrm{~V}$ (the most precise) or the oxidation intensity current at $0.41 \mathrm{~V}$.

Finally, a cleaning procedure for the working electrode must be applied. This step has been previously performed with classical cleaning protocols using a $\mathrm{H}_{2} \mathrm{SO}_{4}$ solution; however, for in situ seawater measurements, this process is not suitable. A new procedure has been developed which consists in applying a potential of $-0.2 \mathrm{~V}$ during $200 \mathrm{~s}$ in an seawater sample. This method has been successfully tested using classical gold or platinum macroelectrodes ( $2 \mathrm{~mm}$ of diameter) by applying it between different measurements of a sample containing a silicate concentration of 140 $\mu$ mol. $L^{-1}$. The measured current in the detection cyclic voltammograms showed a variation of only $4.6 \%$ after 18 different measurements over 87 days.

\section{Results and discussion}




\subsection{Contamination tests}

The microdevices presented in this work were tested by measuring a $140 \mu \mathrm{mol} . \mathrm{L}^{-1}$ silicate solution made in sodium chloride solution. After the Mo oxidation, the silicomolydic complex detection was carried out with a microdevice directly immersed inside the $3 \mathrm{~mL}$ sample contained in the cell shown in Figure 2 (it was only needed to insert the side where are the electrodes of the microdevices). The silicate measurement was repeated several times in the same sample and an unexpected increase of the analytical signal with time was observed. Since all components from the microdevice were in contact with the sample during the detection process, a possible release of silicates was suspected from one or more of the microdevice components. Thus, a contamination study in sodium chloride solution was performed and the following materials were analysed one by one: i) an oxidized silicon wafer $\left(\mathrm{SiO}_{2}\right.$ : thickness: $\left.1 \mu \mathrm{m}\right)$ where the metallic electrodes are deposited; ii) a silicon oxide wafer with $\mathrm{a} \mathrm{Si}_{3} \mathrm{~N}_{4}$ passivation layer (Figure $1 \mathrm{~A}-\mathrm{a}$ ); iii) a silicone resin covering the electric micro-connections between the electrodes and the electric paths on the printed circuit board (Figure 1A-b); iv) a PolyChloroBiphenyl (PCB) plate where are the electric paths (Figure 1A-c).

Each material/component was immersed separately in different $\mathrm{NaCl}$ solutions during at least 10 minutes and, then, a silicate detection procedure (section 2.4) was applied. Cyclic voltammograms were recorded using a homemade gold ultramicroelectrode (see section 2.2) coupled with an $\mathrm{Ag} / \mathrm{AgCl} / \mathrm{KCl}$ (3 mol. $\mathrm{L}^{-1}$ ) reference electrode and a platinum counter electrode. Figure 3 shows a comparison between results obtained in a blank solution (only $\mathrm{NaCl}$ solution) and the different samples in contact with every component of the microdevices.

The signal obtained on Figure 3-A with the oxidized silicon wafer without the $\mathrm{Si}_{3} \mathrm{~N}_{4}$ layer (i: red line) shows a small peak at $0.30 \mathrm{~V}$ that might correspond to the silicomolybdic complex, indicating a release of silicates in the solution. However when the silicon wafer is covered with the passivation layer (ii: blue line) it did not 
provide any contamination to the solution (see Figure 3-A). The silicon resin (iii) and the PCB printed circuit board (iv) clearly released silicates to the solution. The measurements of these solutions showed an oxidation peak corresponding to the silicomolybdic complex (Figure 3-B). For the resin, it has been also observed that the signal increases even more for longer immersion times up to 12 hours (see Figure 3B). Therefore, components (iii) and (iv) must be isolated from the sample during its measurement.

An electrochemical cell has been developed where one microdevice can be integrated into it (see scheme in Figure 4) and allows to put only the electrode surfaces in contact with the sample during a measurement while the rest of the device, susceptible of releasing silicates, is properly isolated from the solution. This cell is made of Poly(methyl methacrylate) (PMMA) and has two distinct parts: at the bottom, there is a base where the microdevice is attached and, at the top, there is a reservoir where the sample is added (once the oxidation and complexation has been performed, for instance, using the procedure and cell described in section 2.4). Between the reservoir and the microdevice, a waterproof seal is placed to prevent the contact of the solution with other microdevice components apart from the electrodes and avoid any release of silicate. As a validation of the good device insulation, a synthetic seawater solution was kept in the cell reservoir with a microdevice attached into it for several days. The measurements performed afterwards did not detect any release of silicates to the sample.

\subsection{Passivation layers study}

A big challenge is the development of capping passivation layers for electrochemical devices that provide the required accuracy and robustness for continuous analysis in seawater. $\mathrm{Si}_{3} \mathrm{~N}_{4}$ has been the material tested for the passivation layer in the electrochemical devices described in this work, either when the working electrodes 
are made of gold or platinum (ME and UME, see section 2.1). The effectiveness of the $\mathrm{Si}_{3} \mathrm{~N}_{4}$ insulating layer has been checked by observing the state of the gold and platinum electrodes with Scanning Electron Microscopy (SEM Hitachi S4800) once 20 measurements of samples with different silicates concentrations had been performed. Gold electrodes did not present a proper adherence to the $\mathrm{Si}_{3} \mathrm{~N}_{4}$ passivation layer in silicate solutions which led to strong damages on them and, thus, to an increase of their electroactive area surface. This resulted in a lack of accuracy and reproducibility on their silicate determinations increasing with the number of uses of the microdevices. Figure 5 shows both the damages observed by SEM on two representative ultramicroelectrodes from one microdevice (see Figure 5, inserts) and the evolution of cyclic voltammograms corresponding to three different detections of the same solution of $140 \mu \mathrm{mol} . \mathrm{L}^{-1}$ of silicates. Between the first and third detection, the analytical signal measured with the first UME increased more than three times (Figure 5-A) and, for the second UME, the signal nearly doubled (Figure 5-B).

Same results were obtained for the gold macroelectrode (see Figure 6), which led to the conclusion that gold is not appropriate for silicate determinations under the conditions used in this work. Moreover, the silver reference electrode also presented seawater infiltrations underneath the silicon nitride (results not shown). Studies and improvements are still underway for isolating properly this electrode but, meanwhile, an external reference can be used for any silicate determination with no problems even in the final version of the in situ sensor.

The platinum electrodes showed a good adherence with silicon nitride in seawater. The layer stayed intact on the corresponding electrodes even after several experiments or several days of immersion in seawater with silicates (see counter electrode on Figure 6). Thus, platinum has been chosen as the material for the microdevices working electrodes (the counter electrode is also made of platinum). 


\subsection{Analytical performances}

Twelve different microdevices with platinum working electrodes (all the devices presented one ME of $2 \mathrm{~mm}$ of diameter and four UME of $15 \mu \mathrm{m}$ of diameter) were tested by applying calibration measurements using the analytical procedures explained in sections 2.4 and the cell presented on Figure 4. Different concentrations of silicate were prepared between 0.50 and $12.12 \mu \mathrm{mol} . \mathrm{L}^{-1}$ and from 8.42 to 134.8 $\mu$ mol. $\mathrm{L}^{-1}$ in sodium chloride solution, to cover the whole range of those found in the open ocean. An external $\mathrm{Ag} / \mathrm{AgCl} / \mathrm{KCl}\left(3 \mathrm{~mol} . \mathrm{L}^{-1}\right)$ reference electrode was used for all the measurements. The analytical signal was the intensity current measured in the $0.38 \mathrm{~V}$ reduction peak of their corresponding cyclic voltammograms. Among the twelve analysed microsensors, only one presented mechanical problems and did not provide any measurable signal. This device will not be taken into account for the following description of the devices analytical behaviour.

On one hand, silicate calibrations carried out with the macroelectrodes showed excellent results: $91 \%$ of the analysed MEs showed linear regressions superior to $\mathrm{R}^{2}$ $=0.995$ which demonstrate their outstanding analytical performance. As an example, in Figure 7, two different calibrations (high concentration range) performed within a month of difference are presented (square and circle markers) using the ME of one microdevice for a concentration range from 8.42 to $134.8 \mu \mathrm{mol}^{-\mathrm{L}^{-1}}$. The agreement between both calibrations proves the good reproducibility that can be achieved with the macroelectrode. In fact, a low average deviation of $2.8 \%$ was obtained for currents measured repeatedly during a month using the same ME in a solution containing $67.1 \mu \mathrm{mol} . \mathrm{L}^{-1}$ of silicates. After 3 months, the measurements could be replicated using the same microdevice. Similar results were obtained in a 134.8 $\mu$ mol. $\mathrm{L}^{-1}$ silicate sample. The sensitivity of the microdevices ME is also excellent, given by the excellent signal-to-noise ratio shown in Figure 7-A. On Figure 7-B, the triangle markers correspond to the calibration obtained for the lowest concentration 
range from 0.50 to $12.12 \mu \mathrm{mol} . \mathrm{L}^{-1}$ reported also in the insert of Figure 7-B with a larger scale. The limit of detection with $\mathrm{ME}$ is $0.50 \mu \mathrm{mol} . \mathrm{L}^{-1}$. Altogether, the results obtained with the macroelectrodes demonstrate their remarkable precision, reproducibility, good stability and sensitivity that make them very useful for proper oceanographic applications.

On the other hand, $43 \%$ of all analysed ultramicroelectrodes in the devices (the total number of UMEs tested was 44) showed a high analytical accuracy with calibrations where $R^{2} \geq 0.99$ was obtained. More interesting is that seven of the eleven microdevices tested had at least one ultramicroelectrode with this excellent performance. Figure 8 shows both the different cyclic voltammograms of a silicate calibration performed with one ultramicroelecrode from a microdevice and the corresponding calibration curve (the analytical signal has been the current intensity measured in the reduction wave of the cyclic voltammograms). The limit of quantification obtained with UMEs is $8.44 \mu \mathrm{mol} . \mathrm{L}^{-1}$.

It has been observed that, for the same silicate sample, the current intensity measured are not exactly reproducible between ultramicroelectrodes (even on the same microdevice). An inaccuracy on the UME surface during the microdevice fabrication seems to be the reason. Electrodes are fabricated with an imprecision of $\pm 1 \mu \mathrm{m}$ on their diameter. For UMEs, this imprecision can lead to differences sufficiently large in their electroactive surface and, thus, to a difference on the measured currents for the same silicate concentration. This should not be a problem as the exact electroactive surface of UMEs can be electrochemically determined by analysing well known systems such as the ferri/ferrocyanide redox systems [46].

The presence of a ME and four UME altogether in a same microdevice offers a great advantage since it allows performing up to five automatic sequential silicate detections using a potentiostat and a MUX module (see Section 2.2). This provides to 
the user a wider range of results and a better accuracy for the silicate concentration measurement. Moreover, the combination of detection experiments from both $\mathrm{ME}$ and UME paves the way for a future calibrationless procedure [51].

Platinum microdevices, especially using the integrated macroelectrodes, have provided excellent results and could be successfully integrated in silicate microsensors for oceanographic research. They will allow also to reduce the cost of the sensor and to facilitate its miniaturisation, as the design of the microdevices can be adapted as desired to fit into very small cells.

\section{Conclusions}

New silicon-based electrochemical microdevices with $\mathrm{Si}_{3} \mathrm{~N}_{4}$ passivation layer, deposited at low temperature by ICP-CVD coupled with a non-aggressive lift-off process, have been developed for the determination of nutrients in seawater. A microdevice combines one macroelectrode (2 $\mathrm{mm}$ of diameter), four ultramicroelectrodes (15 $\mu \mathrm{m}$ of diameter), one platinum counter electrode and one silver electrode that can be used a reference electrode in seawater after chlorination. All the components of microdevices have been immersed individually in seawater during 10 minutes and the resulting solutions have been analysed using the electrochemical procedure for silicate determination. It appears that some of the materials used for the fabrication of the microdevice release silicates to the sample and contaminate it. Therefore, a new cell has been developed where the devices are inserted during the detection process in order to isolate all their components from the solution except the electrodes. Two different metals ( $\mathrm{Au}$ and $\mathrm{Pt})$ have been evaluated as working electrodes for in situ detection of silicate in seawater. On one hand, gold is not suitable for seawater applications since infiltrations of water were observed underneath the passivation layer due to a weak adherence between gold and $\mathrm{Si}_{3} \mathrm{~N}_{4}$ layer in such a corrosive medium. 
On the other hand, platinum working electrodes gave good results. Silicate calibrations, between 0.50 and $134.8 \mu \mathrm{mol}^{-\mathrm{L}^{-1}}$, in synthetic seawater have been performed to test the analytical performance of the microdevices. Ten of the eleven studied platinum macroelectrodes showed excellent linear regressions $\left(R^{2}>0.995\right)$, very good limit of detection $\left(0.50 \mu \mathrm{mol} . \mathrm{L}^{-1}\right)$ and remarkable stability, lifetime and reproducibility as only $2.8 \%$ of the signal for a $67.1 \mu \mathrm{mol}^{-L^{-1}}$ silicate sample decreased after 4 months of use. Moreover, seven of the eleven microdevices had at least one ultramicroelectrode that provided linear regressions superior to $0.99 \%$ in silicate calibrations. Work is underway to improve even more the performance of ultramicroelectrodes.

Altogether, the new Pt microdevices can be integrated in electrochemical sensors for the in situ determination of nutrients concentration in seawater. The sensors will be easily adaptable on different platforms due to the small size, low weight and low cost of fabrication of the microdevices. These properties will also allow the multiplication of the sensors to increase the spatio-temporal resolution of silicate data in the global ocean. 


\section{Acknowledgements}

William Giraud and Emilie Vanhove were supported by the Foundation STAE (Sciences and Technologies for Space and Aeronautics, http://www.fondationstae.net/) in the Midi-Pyrénées region within the project "MAISOE" (Microlaboratories of in situ Analysis for Environmental Observatories). David Aguilar was supported by the SenseOCEAN project: Marine sensors for the $21^{\text {st }}$ Century funded by the European Commission Seventh Framework Programme under Grant Agreement 614141 (http://www.senseocean.eu/). Technological realizations were partly supported by the French RENATECH network. The authors want to thank Professor Maurice Comtat from Laboratoire de Génie Chimique in Toulouse for helpful discussions. 


\section{References}

[1] J. Wang, Analytical Electrochemistry, 2nd edition,Wiley-VCH, 2001, pp. 222

[2] D. Zheng, X. Liu, H. Cao, S. Zhu, Y. Chen, An Electrochemical Microsensor for the Detection of Nitric Oxide, Anal. Lett. 46 (2013) 790-802

[3] S. N. Robledo, V.G.L. Zachetti, M.A. Zon, H. Fernández, Quantitative determination of tocopherols in edible vegetable oils using electrochemical ultramicrosensors combined with chemometric tools, Talanta 116 (2013) 964-971

[4] J. Orozco, C. Fernández-Sánchez, C. Jiménez-Jorquera, Ultramicroelectrode Array Based Sensors: A Promising Analytical Tool for Environmental Monitoring, Sensors 10 (2010) 475-490

[5] C.E. Reimers, Applications of microelectrodes to Problems in Chemical Oceanography, Chem. Rev. 107 (2007) 590-600

[6] T.S. Moore, K.M. Mullaugh, R.R. Holyoke, A.S. Madison, M.Yücel, G.W. Luther III, Marine Chemical Technology and Sensors for Marine Waters: Potentials and Limits, Annu. Rev. Mar. Sci. 1 (2009) 91-115

[7] G. Denuault, Electrochemical techniques and sensors for ocean research, Ocean Sci. 5 (2009) 697-710

[8] A.R. Abdur Rahman, S. Bhat, S. Bhansali, Design, fabrication, and impedance characterization of a capacitance-based salinity sensor for marine applications, J. Electrochem. Soc. 155 (2008) 355-360

[9] P. Zhao, W.-J. Cai, pH polymeric membrane microelectrodes based neutral carriers and their application in aquatic environments, Anal. Chim. Acta 395 (1999) 285-291

[10] N. Le Bris, P.M. Sarradin, S. Pennec, A new deep-sea probe vent biological communities, Deep-Sea Res. I 48 (2001) 1941-1951

[11] K. Ding, W.E. Seyfried, In situ measurement of $\mathrm{pH}$ and dissolved $\mathrm{H}_{2}$ in midocean ridge hydrothermal fluids at elevated temperatures and pressures, Chem. Rev. 107 (2007) 601-6022 
[12] T.R. Martz, J.G. Connery, K.S. Johnson, Testing the Honeywell Durafet ${ }^{\circledR}$ for seawater pH applications, Limnol. Oceanogr.: Methods 8 (2010) 172-184

[13] O. Nir, E. Marvin, O. Lahav, Accurate and self-consistent procedure for determining $\mathrm{pH}$ in seawater desalination brines and its manifestation in reverse osmosis modelling, Water Res. 64 (2014) 187-195

[14] T. Komada, C.E. Reimers, S.E. Boehme, Dissolved inorganic carbon profiles and fluxes determined using pH and pCO2 microelectrodes, Limnol. Oceanogr. 43 (1998) 769-781

[15] T. Ishiji, D.W. Chipman, T. Takahashi, K. Takahashi, Amperometric sensor for monitoring of dissolved carbon dioxide in seawater, Sens. Actuators, B 76 (2001) 265-269

[16] M. Whitfield and D. Jagner, Marine electrochemistry: A practical introduction, Wiley, pp. 542, 1981

[17] N.P. Revsbech, An oxygen microelectrode with a guard cathode, Limnol. Oceanogr. 34 (1989) 472-476

[18] N.P. Revsbech, L.H. Larsen, J. Gundersen, T. Dalsgaard, O. Ulloa, B. Thamdrup, Determination of ultra-low oxygen concentrations in oxygen minimum zones by the STOX sensor, Limnol. Oceanogr.: Methods 7 (2009) 371-381

[19] N.P. Revsbech, B. Thamdrup, J.T. Dalsgaard, D.E. Canfield, Construction of STOX Oxygen Sensors and Their Application for Determination of $\mathrm{O}_{2}$ Concentrations in Oxygen Minimum Zones, Methods Enzymol. 486 (2011) 325-341

[20] G.W. Luther III, B.T. Glazer, S. Ma, R. E. Trouwborst, T.S. Moore, E. Metzger, C. Kraiya, T.J. Waite, G. Druschel, B. Sundby, M. Taillefert, D.B. Nuzzio, T.M. Shank, B.L. Lewis, P.J. Brendel, Use of voltammetric solid-state (micro)electrodes for studying biogeochemical processes: Laboratory measurements to real time measurements with an in situ electrochemical analyzer (ISEA), Mar. Chem. 108 (2008) 221-235

[21] M.-L. Tercier-Waeber, F. Confalonieri, G. Riccardi, A. Sina, S. Nöel, J. Buffle, F. Graziottin, Multi Physical-Chemical profiler for real-time in situ monitoring of trace metal speciation and master variables: Development, validation and field applications, Mar. Chem. 97 (2005) 216-235 
[22] R. Güell, G. Aragay, C. Fontàs, E. Anticó, A. Merkoçi, Sensitive and stable monitoring of lead and cadmium in seawater using screen-printed electrode and electrochemical stripping analysis, Anal. Chim. Acta 627 (2008) 219-224

[23] K. Malzahn, J.R. Windmiller, G. Valdés-Ramírez, M.J. Schöning, J. Wang, Wearable electrochemical sensors for in situ analysis in marine environments, Analyst 136 (2011) 2912-2917

[24] G. Herzog, W. Moujahid, K. Twomey, C. Lyons, V.I. Ogurtsov, On-Chip electrochemical microsystems for measurements of copper and conductivity in artificial seawater, Talanta 116 (2013) 26-32

[25] A. Berduque, Y.H. Lanyon, V. Beni, G. Herzog, Y.E. Watso, K. Rodgers, F. Stam, J. Alderman, D.W.M. Arrigan, Voltammetric characterisation of silicon-based microelectrode arrays and their application to mercury-free stripping voltammetry of coppers ions, Talanta 71 (2007) 1022-1030

[26] W. Moujahid, P. Eichelmann-Daly, J. Strutwolf, V.I. Ogurtsov, G. Herzog, D.W.M. Arrigan, Microelectrochemical Systems on Silicon Chips for the Detection of Pollutants in Seawater, Electroanal. 23 (2001) 147-155

[27] J. Buffle, M.-L. Tercier-Waeber, Voltammetric environmental trace-metal analysis and speciation: from laboratory to in situ measurements, Trends Anal. Chem. 24 (2005) 172-191

[28] C. Colombo, C.M.G. Van den Berg, A. Daniel, A flow cell for on-line monitoring of metals in natural waters by voltammetry with a mercury drop electrode, Anal. Chim. Acta 346 (1997) 101-111

[29] E.P. Achterberg, C.M.G. Van den Berg, C. Colombo, High resolution monitoring of dissolved $\mathrm{Cu}$ and $\mathrm{Co}$ in coastal surface waters of the Western North Sea, Cont. Shelf Res. 23 (2003) 611-623

[30] M.-L. Tercier, J. Buffle, F. Graziottin, A Novel Voltammetric In-Situ Profiling System for Continuous Real-Time Monitoring of Trace Elements in Natural Waters, Electroanal. 10 (1998) 355-363

[31] C. Belmont, M.-L. Tercier, J. Buffle, G.C. Fiaccabrino, M. Koudelka-Hep, Mercury-plated iridium-based microelectrode arrays for trace metals detection by voltammetry: optimum conditions and reliability, Anal. Chim. Acta 329 (1996) 203-214 
[32] R. Feeney, S.P. Kounaves, On-Site Analysis of Arsenic in Groundwater Using a Microfabricated Gold Ultramicroelectrode Array, Anal. Chem. 72 (2000) 2222-2228

[33] M.-L. Tercier, N. Parthasarathy, J. Bufle, Reproducible, reliable and rugged Hgplated Ir-based microelectrode for in situ measurements in natural waters, Electroanal. 7 (1995) 55-63

[34] M.-L. Tercier-Waeber, J. Pei, J. Buffle, G.C. Fiaccabrino, M. Koudelka-Hep, G. Riccardi, F. Confalonieri, A. Sina, F. Graziottin, A Novel Voltammetric Probe with Individually Addressable Gel-Integrated Microsensor Arrays for Real-Time High Spatial Resolution Concentration Profile Measurements, Electroanalysis 12 (2000) 27-34

[35] G.W. Luther III, P.J. Brendel, B.L. Lewis, Simultaneous measurement of O2, Mn, $\mathrm{Fe}, \mathrm{I}$, and $\mathrm{S}(-\mathrm{II})$ in marine pore waters with a solid-stage voltammetric microelectrode, Limnol. Oceanogr. 43 (1998) 325-333

[36] G.W. Luther III, B.T. Glazer, L. Hohmann, J.I. Popp, M. Taillefert, T.F. Rozan, P.J. Brendel, S.M. Theberge, D.B. Nuzzio, Sulfur speciation monitored in situ with solid state gold amalgam voltammetric microelectrodes: polysulfides as a special case in sediments, microbial mats and hydrothermal vent waters, J. Environ. Monit. 3 (2001) 61- 66

[37] B. Sundby, M. Caetano, C. Vale, C. Gobeil, G.W. Luther III, D.B. Nuzzio, RootInduced Cycling of Lead in Salt Marsh Sediments, Environ. Sci. Technol. 39 (2005) 2080-2086

[38] M. Lacombe, V. Garçon, M. Comtat, L. Oriol, J. Sudre, D. Thouron, N. Le Bris, C. Provost, Silicate determination in sea water: Toward a reagentless electrochemical method, Mar. Chem. 106 (2007) 489-497

[39] M. Lacombe, V. Garçon, D. Thouron, N. Le Bris, M. Comtat, Silicate electrochemical measurements in seawater: Chemical and analytical aspects towards a reagentless sensor, Talanta 77 (2008) 744-750

[40] R. Feeney, S.P. Kounaves, Microfabricated Ultramicroelectrode Arrays: Developments, Advances, and Applications in Environmental Analysis, Electroanalysis 12 (2000) 677-684

[41] A.K. Diallo, L. Djeghlaf, L. Mazenq, J. Launay, W. Sant, P. Temple-Boyer, Development of pH-based ElecFET biosensors for lactate ion detection, Biosens. Bioelectron. 40 (2013) 291-296 
[42] C. Christophe, F. Sékli Belaidi, J. Launay, P. Gros, E. Questel, P. Temple-Boyer, Elaboration of integrated microelectrodes for the detection of antioxidant species, Sens. Actuators, B 177 (2013) 350-356

[43] G. Schmitt, J.-W. Schultze, F. Faßbender, G. Buß, H. Lüth, M.J. Schöning, Passivation and corrosion of microelectrode arrays, Electrochim. Acta 44 (1999) 3865-3883

[44] A. Tsopela, A. Lale, E. Vanhove, O. Reynes, I. Séguy, P. Temple-Boyer, P. Juneau, R. Izquierdo, J. Launay, Integrated electrochemical biosensor based on algal metabolism for water toxicity analysis, Biosens. Bioelectron. 61 (2014) 290-297

[45] M.A. Nolan, S.P. Kounaves, Failure analysis of microfabricated iridium ultramicroelectrodes in chloride media, Sens. Actuators, B 50 (1998) 117-127

[46] E. Vanhove, A. Tsopéla, L. Bouscayrol, A. Desmoulin, J. Launay, P. TempleBoyer, Final capping passivation layers for long-life microsensors in real fluids, Sens. Actuators, B 178 (2013) 350-358

[47] M. Aufray, A.A. Roche, Residual Stresses and Practical Adhesion: Effect of Organo-metallic Complex Formation and Crystallization, J. Adhes. Sci. Technol. 20 (2006) (16), pp. 1889-1903

[48] J. Jońca, C. Barus, W. Giraud, D. Thouron, V. Garçon, M. Comtat, Electrochemical behaviour of isopoly- and heteropolyoxomolybdates formed during anodic oxidation of molybdenum in seawater, Int. J. Electrochem. Sci. 7 (2012) 73257348

[49] N.G. Carpenter, A.W.E Hodgson, D. Pletcher, Microelectrode Procedures for the Determination of Silicate and Phosphate in Waters - Fundamental Studies, Electroanalysis 9 (1997) 1311-1317

[50] A.W.E. Hodgson, D. Pletcher, Microelectrode Procedures of the Analysis of Silicate and Phosphate - Towards Practical Procedures, Electroanalysis 10 (1998) 321-325

[51] W. Giraud, L. Lesven, J. Jońca, C. Barus, L. Gourdal, D. Thouron, V. Garçon, M. Comtat, Reagentless and calibrationless silicates measurement in oceanic water, Talanta 97 (2012) 157-162 


\section{Figure captions:}

Figure 1: A) Photo of microdevice with a) oxidized silicon wafer covered with the electrodes and $\mathrm{Si}_{3} \mathrm{~N}_{4}$ passivation layer, b) silicone resin covering the electric microconnections, c) PolyChloroBiphenyl (PBC) plate, d) printed circuit board and e) connection pin. B) Zoom on the electrodes with the silver electrode (Ag), the platinum counter electrode $(\mathrm{Pt})$, the macroelectrode $(\mathrm{ME}, \phi=2 \mathrm{~mm})$ and 4 ultramicroelectrodes (small dots around the ME) and C) Zoom on one ultramicroelectrode (UME, $\phi=15$ $\mu \mathrm{m})$.

Figure 2: Scheme of the homemade cell designed for the Mo oxidation and the formation of the silicomolybdic complex.

Figure 3: Cyclic voltammograms recorded with a gold ultramicroelectrode with 10 $\mathrm{mV} . \mathrm{s}^{-1}$ (IPDA, $25 \mu \mathrm{m}$ diameter) and an $\mathrm{Ag} / \mathrm{AgCl} / \mathrm{KCl}\left(3 \mathrm{~mol}^{-1} \mathrm{~L}^{-1}\right)$ reference electrode in: A) sodium chloride solution alone (black line), seawater where the silicon wafer was immersed (red line), seawater where a silicon wafer covered with $\mathrm{Si}_{3} \mathrm{~N}_{4}$ was immersed (blue line); B) sodium chloride solution alone (black line), seawater where silicon resin was immersed for 10 minutes (blue line), seawater where silicon resin was immersed for 12 hours (red line), seawater where PCB was immersed (green line).

Figure 4: Scheme of the cell adapted for the microdevices and the silicate detection measurement.

Figure 5: Evolution with time of cyclic voltammograms obtained in sodium chloride solution containing $140 \mu \mathrm{mol} . \mathrm{L}^{-1}$ of silicates using two gold UMEs (A and B) and 
Platinum counter electrode from the same microdevice and an external $\mathrm{Ag} / \mathrm{AgCl} / \mathrm{KCl}$ $3 \mathrm{~mol} . \mathrm{L}^{-1}$ reference electrode; scan rate $5 \mathrm{mV} . \mathrm{s}^{-1}$ (blue line) $1^{\text {st }}$ detection, (red line) $2^{\text {nd }}$ detection and (green line) $3^{\text {rd }}$ detection - Inserts $A$ and B correspond to SEM observations of the gold UMEs in the center and the damaged $\mathrm{Si}_{3} \mathrm{~N}_{4}$ layer.

Figure 6: Photo of a Scanning Electron Microscopy observation of a microdevice with gold ME and UME electrodes and a platinum counter electrode. In yellow/beige: Au; In grey: Pt; In blue: passivation layer $\left(\mathrm{Si}_{3} \mathrm{~N}_{4}\right)$ on the $\mathrm{Pt}$; In light yellow: passivation layer $\left(\mathrm{Si}_{3} \mathrm{~N}_{4}\right)$ on $\mathrm{Au}$; In green: passivation layer $\left(\mathrm{Si}_{3} \mathrm{~N}_{4}\right)$ on silicon oxide.

Figure 7: A) Cyclic voltammograms obtained in an sodium chloride solution containing $\left[\mathrm{Si}(\mathrm{OH})_{4}\right]=8.42$ (blue line), 33.69 (red line) , 67.38 (green line), 101.08 (orange line), 134.77 (black line) $\mu \mathrm{mol}^{-\mathrm{L}^{-1}}$ using the platinum working macroelectrode and $\mathrm{Pt}$ counter electrode from a microdevice and an external $\mathrm{Ag} / \mathrm{AgCl} / \mathrm{KCl}\left(3 \mathrm{~mol} . \mathrm{L}^{-1}\right)$ reference electrode; scan rate $100 \mathrm{mV} \cdot \mathrm{s}^{-1}$. B) Calibration curves obtained between 8.42 and $134.77 \mu \mathrm{mol} . \mathrm{L}^{-1}$ within a month of difference ( $\square$ and $\circ$ markers) and between 0.50 and $12.12 \mu$ mol. $\mathrm{L}^{-1}$ ( $\triangle$ markers) - Insert: zoom of calibration curve obtained between 0.50 and $12.12 \mu \mathrm{mol}^{\mathrm{L}} \mathrm{L}^{-1}$.

Figure 8: A) Cyclic voltammograms obtained in an sodium chloride solution containing $\left[\mathrm{Si}(\mathrm{OH})_{4}\right]=8.44$ (blue line), 33.52 (red line), 67.14 (green line), 100.82 (orange line), 134.12 (black line) $\mu \mathrm{mol}^{-\mathrm{L}^{-1}}$ using a platinum working ultramicroelectrode and Pt counter electrode from a microdevice and an external $\mathrm{Ag} / \mathrm{AgCl} / \mathrm{KCl}\left(3 \mathrm{~mol} . \mathrm{L}^{-1}\right)$ reference electrode; scan rate $10 \mathrm{mV} . \mathrm{s}^{-1}$. B) Calibration curve obtained measuring the intensity current of the reduction wave in the corresponding cyclic voltammograms.

\section{Figure 1:}



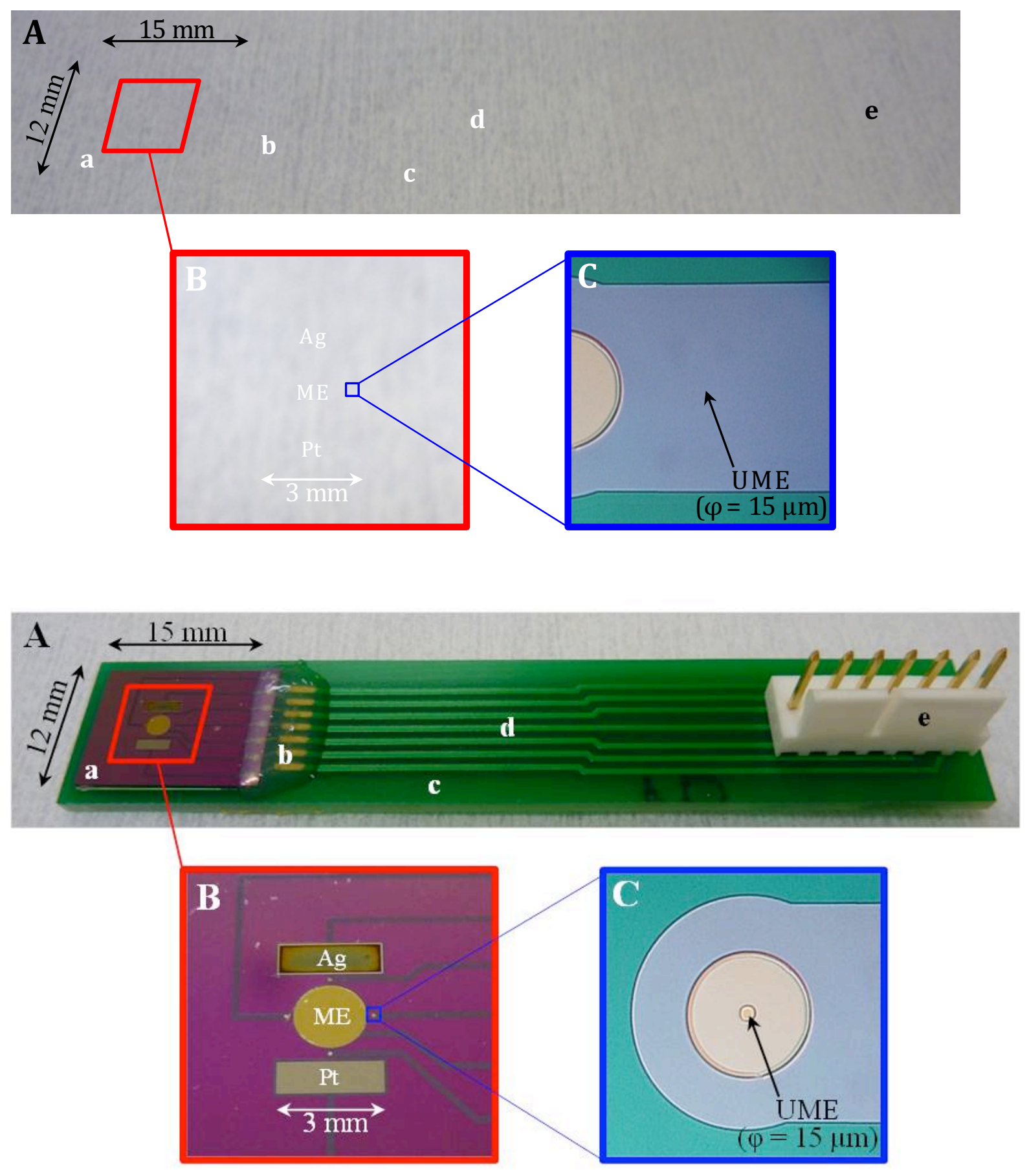
Figure 2:

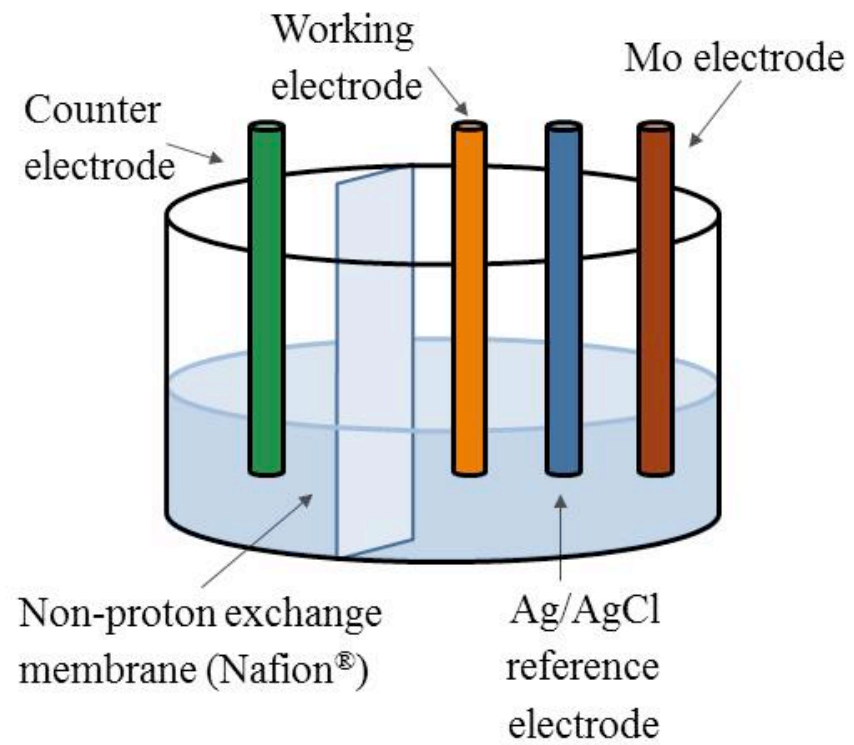


Figure 3:
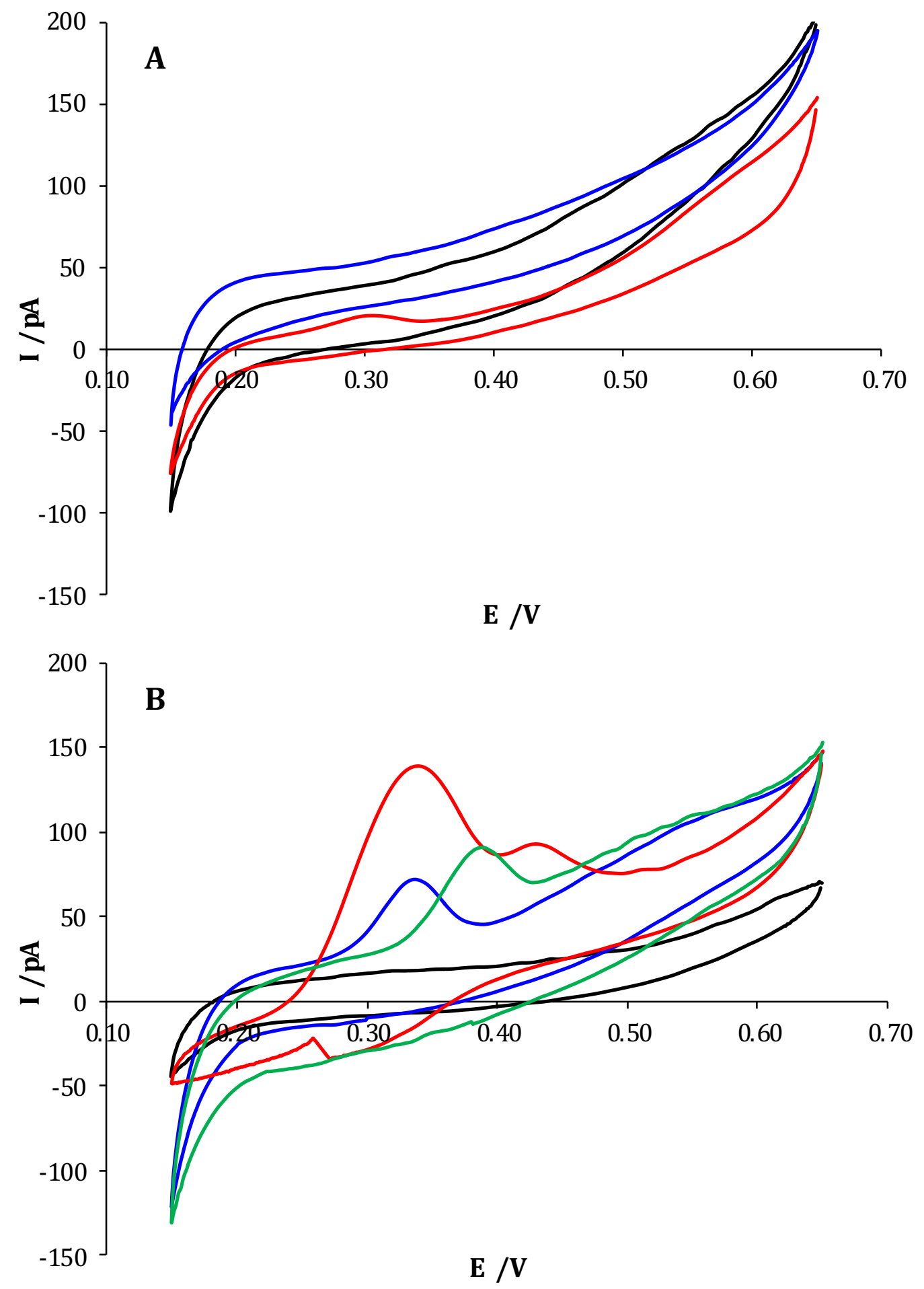
Figure 4:

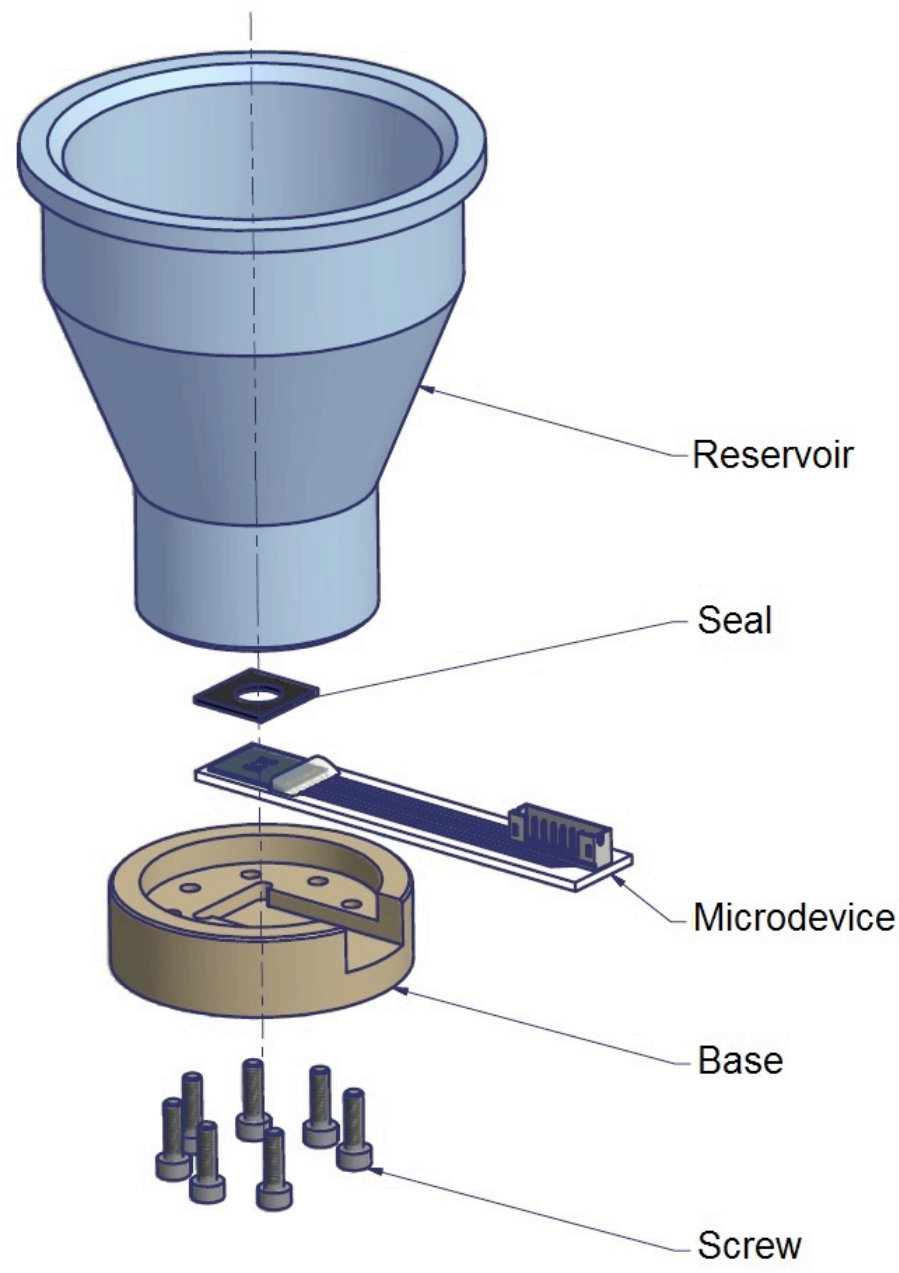


Figure 5:
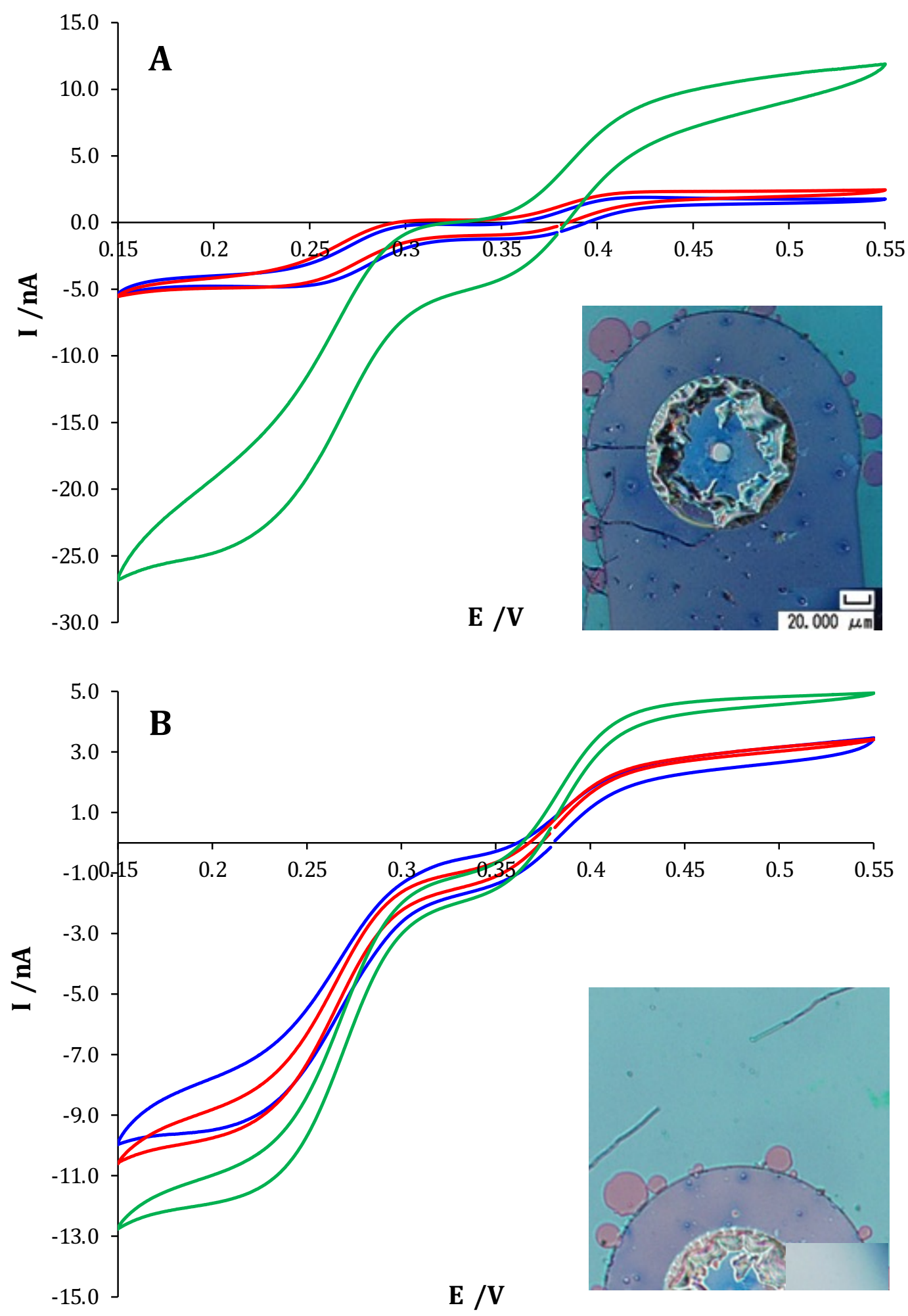
Figure 6:

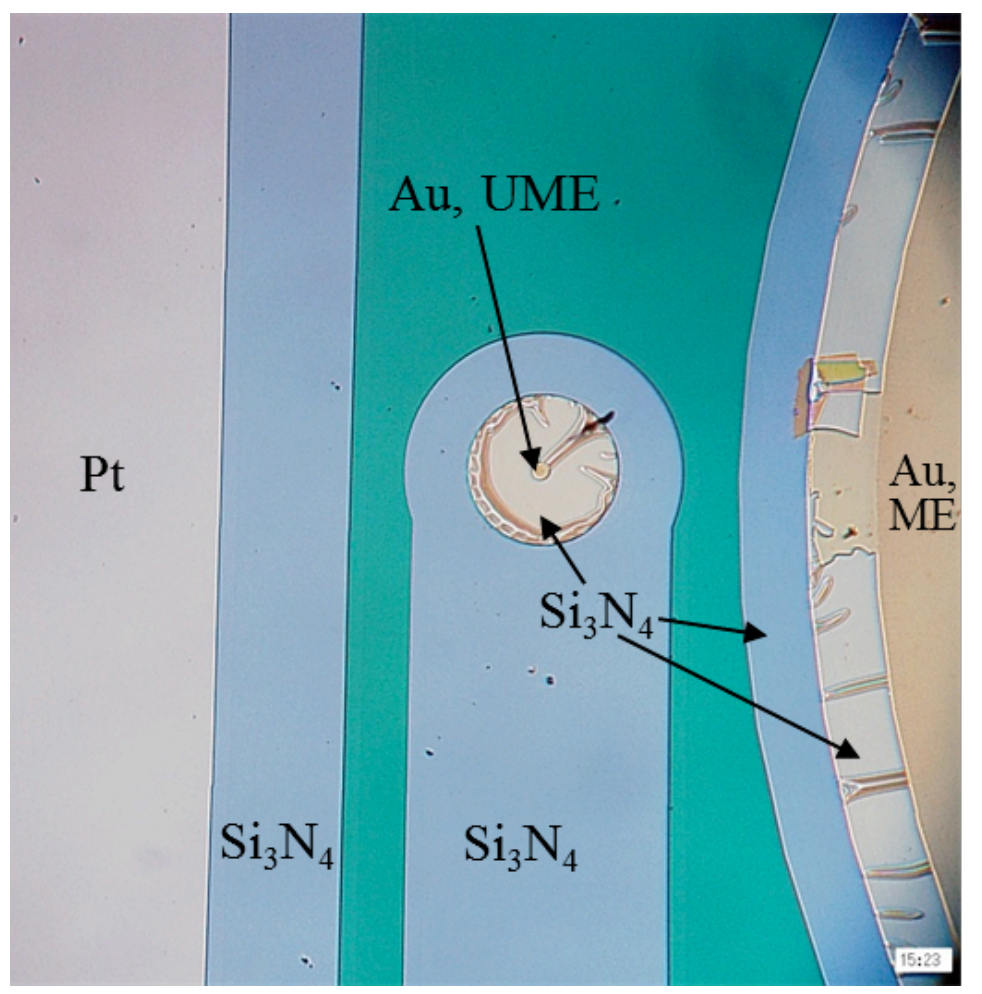


Figure 7:

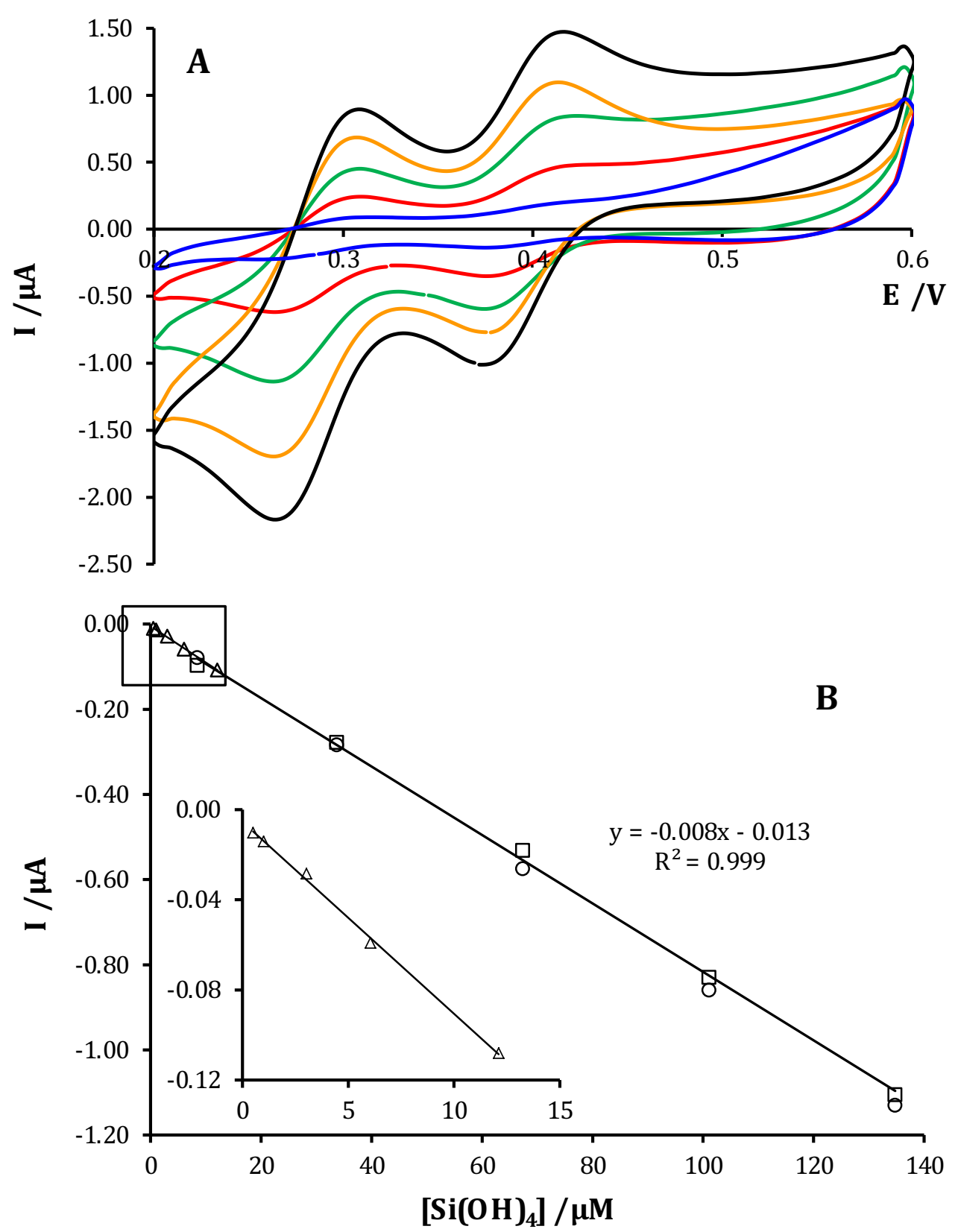


Figure 8:

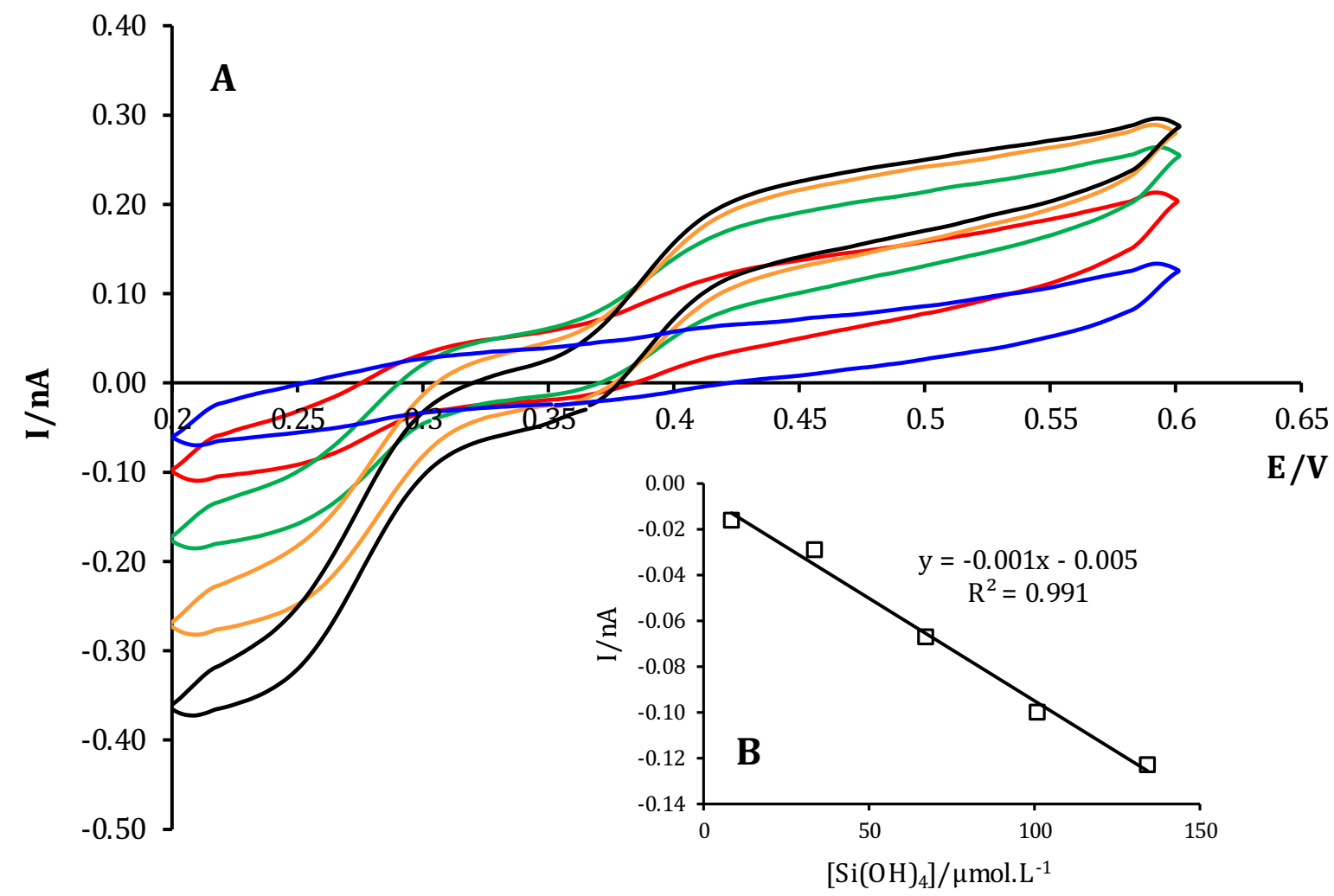

